DOI 10.15290/cnisk.2018.01.04.02

DR HAB. ADAM MIODOWSKI, PROF. UWB

orcid.org/0000-0002-2623-955X

Uniwersytet $w$ Białymstoku

\title{
Wielka wojna kobiet. Zaangażowanie sióstr Szwedzkiego \\ Czerwonego Krzyża w niesienie pomocy jeńcom wojennym \\ z armii państw centralnych w przedrewolucyjnej Rosji
}

(1914-1917)

\begin{abstract}
Streszczenie
Kobiety już od starożytności angażowały się w opiekę nad chorymi i rannymi żołnierzami. Do połowy XIX w. pielęgnacja poszkodowanych wojskowych na zapleczu pola walki była dla markietanek jedynie dodatkowym zajęciem. Humanitarny aspekt ich służby zyskał na znaczeniu na przełomie XVIII i XIX w. wraz $z$ intensyfikacja wojen napoleońskich. W okresie wojny krymskiej zachodnioeuropejska opinia publiczna wymusiła na elitach politycznych i wojskowych zgodę na właczenie do obsad szpitali polowych personelu kobiecego. Siostry miłosierdzia, jak i wspomagajace je świeckie wolontariuszki, współdziałając z lekarzami wojskowymi, wspólnie zapoczatkowali w latach 1854-1855 proces rozwoju nowoczesnej medycyny pola walki. Wielka Wojna $z$ racji swej powszechności i wykorzystywania nowoczesnego uzbrojenia przyniosła ze soba nie tylko więcej niż dotąd ofiar śmiertelnych, lecz także niespotykaną wcześniej liczbę rannych i chorych żołnierzy. Globalny konflikt zbrojny lat 1914-1918 wymagał więc zaangażowania kobiet zarówno przy ratowaniu rannych $z$ pola walki i przy ich pielęgnacji w przyfrontowych szpitalach polowych, jak również wyznaczył im nowa rolę, jaka stała się opieka nad będacymi w złej kondycji milionami jeńców wojennych.
\end{abstract}

Słowa kluczowe: Wielka Wojna, jeńcy wojenni w Rosji, siostry Czerwonego Krzyża, pomoc humanitarna, opieka pielęgniarska 


\title{
THE GREAT WAR OF WOMEN. INVOLVEMENT OF THE SWEDISH RED CROSS SISTERS IN HELPING PRISONERS OF WAR FROM THE ARMIES OF CENTRAL EUROPEAN COUNTRIES IN PRE-REVOLUTIONARY RUSSIA (1914-1917)
}

\begin{abstract}
Since ancient times, women have been involved in the care of sick and wounded soldiers. Until the mid- $19^{\text {th }}$ century, the care of the injured on the battlefield was only an additional activity for the sutlers. The humanitarian aspect of their service gained importance at the turn of the $18^{\text {th }}$ and $19^{\text {th }}$ centuries, along with the intensification of the Napoleonic Wars. During the Crimean War, the Western European public opinion forced the political and military elites to agree to include female staff in field hospitals. The Sisters of Mercy, as well as assisting them secular volunteers, jointly initiated the development of modern military medicine in the years 1854-1855. The Great War, due to its universality and the use of modern weapons, brought not only more deaths than ever before, but also an unprecedented number of wounded and sick soldiers. Therefore, the global armed conflict in the years 1914-1918 required the involvement of women not only in rescuing the wounded from the battlefield and taking care of them in the front-line field hospitals, but also set a new role for them, which was taking care of millions of prisoners of war.
\end{abstract}

Keywords: The Great War, prisoners of war in Russia, sisters of the Red Cross, humanitarian aid, nursing care

\section{Tło historyczne zaangażowania kobiet w opiekę pielęgniarska nad rannymi i chorymi żolnierzami}

Kobiety już od starożytności angażowały się w opiekę nad chorymi i rannymi żołnierzami ${ }^{1}$. Do połowy XIX w. pielęgnacja poszkodowanych wojskowych na zapleczu pola walki była dla nich jedynie dodatkowym zajęciem. Podążające za wojskiem markietanki były bowiem przede wszystkim wędrownymi handlarkami sprzedajacymi wojskowym żywność i używki. Równolegle zajmowały się zarobkowo praniem i na-

\footnotetext{
1 Tematyka zwiąana $\mathrm{z}$ zaangażowaniem kobiet $\mathrm{w}$ opieke nad chorymi i rannymi żołnierzami pozostawała dotychczas na marginesie zainteresowań polskiej historiografii. Konsekwencja tego stanu rzeczy jest dominacja publikacji obcojęzycznych przywoływanych w przypisach do tego artykułu.
} 
prawą mundurów, a niejako przy okazji w czasie wojen świadczyły usługi pielęgniarskie. Niektóre $z$ nich wchodziły też w bardziej zażyłe relacje $z$ żołnierzami i podoficerami. $Z$ jednymi i drugimi nieraz wiazały się w stałe zwiazki, prowadzac ich gospodarstwa ${ }^{2}$.

Humanitarny aspekt służby markietanek zyskał na znaczeniu na przełomie XVIII i XIX w. wraz z intensyfikacją wojen napoleońskich. W 1810 r. dowództwo francuskie wydało instrukcje, w których określono podstawowe wymogi, jakie musiały spełniać kandydatki na markietanki. Odtą do służby przy wojsku mogły być powoływane jedynie mężatki, których mężowie przebywali w danej formacji. W intencji twórców instrukcji miało to zapobiec rozwiązłości w wojsku. Ponadto nakazano, by strój markietanek nie odbiegał od barw danego pułku. Odtąd mogły też one korzystać $z$ wojskowej opieki medycznej oraz uzyskały prawo do nagród, jakie otrzymywali zwyczajowo żołnierze. A co zyskała w zamian Wielka Armia? Mogła liczyć na bezwarunkowe zaangażowanie markietanek w niesienie pomocy walczacym i poszkodowanym na polach bitew żołnierzom. Pod gradem kul roznosiły one walczącym żywność, wodę $i$ alkohol. Znosiły rannych z pola walki i niosły im pierwsza, często jedyna pomoc. Nieraz ich odwaga budziła podziw u współczesnych.

Cztery dekady po wojnach napoleońskich kolejny wielki międzynarodowy konflikt zbrojny, jakim była wojna krymska, przyniósł ze soba zagrożenie katastrofą humanitarna na niespotykaną wcześniej skalę. Krwawe żniwo, jakie zbierała wojna toczona na wybrzeżu czarnomorskim, skłoniło służby medyczne obu stron konfliktu do organizowania wojskowych szpitali polowych w bezpośrednim sasiedztwie frontu. Skrócenie dróg transportu rannych na niewiele się jednak zdało. Potrzebujacych pomocy żołnierzy było bowiem tak wielu, że niekiedy wojskowi sanitariusze nie byli w stanie na bieżąco dzielić obowiązków pomiędzy opiekę nad już hospitalizowanymi a oczekujacymi ich pomocy (transportu) rannymi na froncie. Powiększenie stanów osobowych pielęgniarzy poprzez oddelegowanie do służby w szpitalach polowych żołnierzy frontowych nie było możliwe $z$ powodu oporu dowództw walczacych armii.

Tysiącom rannych żołnierzy brytyjskich, francuskich, włoskich, tureckich i rosyjskich groziła więc śmierć. Na linii frontu i w szpitalach polowych warunki były tragiczne, o czym informowali na bieżąco, dzię-

\footnotetext{
2 W okresie wojen napoleońskich można było spotkać rodziny, w których ojciec był szeregowym lub podoficerem, matka markietanka, a syn doboszem.
} 
ki niedawno wynalezionemu telegrafowi, korespondenci prasowi z zachodniej Europy. Obraz humanitarnej katastrofy, do jakiej doszło zima na przełomie lat 1854 / 1855 , wzmacniały publikowane na łamach gazet pierwsze reporterskie fotografie wojenne.

W takich uwarunkowaniach zachodnioeuropejska opinia publiczna (głównie matki i żony żołnierzy) wymusiła na elitach politycznych i wojskowych zgodę na włączenie do obsad szpitali polowych personelu kobiecego. Głos społeczeństwa stał się słyszalny w gabinetach decydentów m.in. poprzez głośne we Francji publikacje prasowe Valérie de Gasparin ${ }^{3}$, a w Wielkiej Brytanii dzięki korespondencjom Williama Howarda Russella ${ }^{4}$ T Thomasa Chenery'ego ${ }^{5}$ publikowanym na łamach „Timesa”. To ulica i prasa przyczyniły się do tego, że na Półwysep Krymski mogły się udać wykwalifikowane pielęgniarki. Były to siostry miłosierdzia, które ukończyły kościelne szkoły pielęgniarskie ${ }^{6}$.

W tym czasie w Rosji nie funkcjonowała opinia publiczna w zachodnioeuropejskim rozumieniu. Tym niemniej i po tej stronie frontu borykano się $z$ takimi samymi problemami. Katastrofa humanitarna dotknęła także rannych żołnierzy rosyjskich. Tu jednak prasa milczała na temat niewygodnych faktów. Pisali wszak o tym lekarze wojskowi w memoriałach kierowanych do cara, w których przekonywali go o konieczności zaangażowania wykwalifikowanych pielęgniarek do pracy w szpi-

\footnotetext{
3 Valérie de Gasparin (1813-1894). Protestancka pisarka religijna i dziennikarka. Współcześni postrzegali ja jako szwajcarską „rewolucyjną konserwatystkę”. Z jej inicjatywy (i męża hr. Agenora de Gasparin) w 1859 r. w Lozannie otwarto pierwszą na świecie świecką zawodową szkołę pielęgniarską La Source. Dopiero rok później tego typu placówkę na Wyspach Brytyjskich uruchomiła Florence Nightingale - The Nightingale Training School. 4 William Howard Russell (1821-1907). Irlandzki dziennikarz, który zasłyną reportażami wojennymi. Uznawany jest za pierwszego w historii korespondenta wojennego i czołowego reportera.

5 Thomas William Chenery (1826-1884). Dziennikarz brytyjski i wybitny orientalista. W 1854 r. „The Times” skierował go jako korespondenta dyplomatycznego do Stambułu, by z perspektywy tureckiej stolicy relacjonował przebieg wojny krymskiej. Kilkukrotnie przebywał też na Półwyspie Krymskim, gdzie wspierał w pracy dziennikarskiej W.H. Russella.

6 Prekursorem idei bezinteresownego zaangażowania kobiet w niesienie pomocy poszkodowanym w wyniku wojen był ks. Wincenty à Paulo (1581-1660). Wspólnie z s. Ludwika de Marillac powołali Zgromadzenie Sióstr Miłosierdzia, zwane szarytkami (fr. Filles de la Charité). W okresie frondy siostry miłosierdzia niosły pomoc dotkniętym nieszczęściami i zniszczeniami wojennymi, w tym rannym wojskowym. $Z$ czasem na wzór katolicki pojawiły się protestanckie i prawosławne wspólnoty sióstr miłosierdzia.
} 
talach polowych ${ }^{7}$. Mikołaj I pozostawał jednak głuchy na ich argumenty. Ci więc zwrócili się do członków rodziny cesarskiej, licząc, że tą drogą uda się przełamać opór władcy. Ta, której się ostatecznie powiodło, była wielka księżna Helena Pawłowna8.

W takich okolicznościach jesienia 1854 r. po obu stronach frontu do niesienia pomocy rannym i chorym żołnierzom zaangażowano siostry miłosierdzia. Chronologicznie jako pierwsza obowiązi na froncie podjęła kobieca służba pielęgniarska zorganizowana przy armii rosyjskiej. Dzięki poparciu wlk. ks. Pawłowny i z rekomendacji Mikołaja Pirogowa, głównego chirurga wojskowego w oblężonym Sewastopolu, zadanie to powierzono siostrom miłosierdzia ze Wspólnoty Podwyższenia Krzyża Świętego. Pierwsza 28-osobowa grupa sióstr dotarła na Krym 9 listopada 1854 r. Do wojskowej służby pielęgniarskiej skierowano łącznie 6 takich grup, które liczyły ogółem 250 sióstr 9 . Pośród nich w sposób szczególny wyróżniła się siostra Dasza Sewastopolska ${ }^{10}$.

W grudniu 1854 r. na Krym wyruszyła też pierwsza grupa irlandzkich i angielskich ${ }^{11}$ sióstr miłosierdzia $z$ katolickiego klasztoru Bermondsey w Londynie, by opiekować się chorymi i rannymi. Na prośbę Sidneya Herberta, sekretarza Admiralicji ds. wojny, skierowano je początkowo do szpitala wojskowego w Scutari (tur. Üsküdar), położonego na przedmieściach azjatyckiej części Stambułu. Po przybyciu kolejnych 22 sióstr część $z$ nich pozostała w Turcji, a pozostałe podjęły pracę w szpitalach

\footnotetext{
Najbardziej aktywny na tym polu był Mikołaj Pirogow (ros. Николай Пирогов). Ten żyjacy w latach 1810-1881 chirurg i anatom, przyrodnik i nauczyciel akademicki (profesor), uznawany jest za prekursora rosyjskiej szkoły chirurgii wojskowej.

8 Helena Pawłowna Romanowa (1806-1873). Urodzona jako Fryderyka Charlotta Maria Wirtemberska. W 1824 r. poślubiła najmłodszego brata cesarskiego, wlk. ks. Michała Romanowa. Przy powtórnym chrzcie przyjęła imię Helena i otczestwo Pawłowna (ros. Еıена Павцовна) nadane jej po carze Pawle I, który był jej teściem.

$9 \quad$ Krestovozdviženskaâ obŝina siester miloserdiâ [w:] Ėnciklopediâ blagotvoritel'nosti. Sankt-Peterburg, [Dostęp: 16.01.2018]. Dostępny w World Wide Web: <https://goo. gl/3Ssrt1>.

${ }_{10}$ Dasza Sewastopolska (1836-1892), a właściwie Daria Michajłowa (ros. Дарья Михайлова). Jedna $z$ pierwszych rosyjskich sióstr miłosierdzia, która w czasie wojny krymskiej zasłynęła wyjattkowym oddaniem oraz opieką nad rannymi i chorymi obrońcami Sewastopola. Zorganizowała w mieście na własny koszt pierwszy punkt pomocy medycznej (zob. J. Čajka, Daša Sevastopol'skaâ - geroinâ Krymskoj vojny, [Dostęp: 16.01.2018]. Dostępny w World Wide Web: <https://goo.gl/93JYiL>).

11 Pierwszą grupę współtworzyło dwanaście irlandzkich i trzy angielskie siostry miłosierdzia - czwarta Angielką była kierująca cała grupa Florence Nightingale (zob. T.C. Meehan, Irish Nurses at the Crimean War, [Dostęp: 16.01.2018]. Dostępny w World Wide Web: $<$ https://goo.gl/Z1uZCF>).
} 
polowych na Krymie ${ }^{12}$. Obiema grupami kierowała Florence Nightinga$1 \mathrm{e}^{13}$, której powierzono stanowisko generalnej przełożonej pielęgniarek w szpitalach armii brytyjskiej. Ona też przed wyjazdem zajmowała się ich szkoleniem w londyńskim Instytucie Pielęgniarek, założonym w 1840 r. przez Elizabeth Fry ${ }^{14}$.

Pośród kobiet zaangażowanych w niesienie pomocy żołnierzom frontowym obok przedstawicielek panujących dynastii (takich jak wlk. ks. Helena) i arystokratek (jak Florence Nightingale) wyróżniła się reprezentująca niższe warstwy społeczne świecka wolontariuszka Mary Seacole ${ }^{15}$.

Zarówno siostry miłosierdzia, jak i wspomagające je świeckie wolontariuszki, współdziałając $z$ lekarzami wojskowymi ${ }^{16}$, wspólnie zapo-

12 Opis relacji między siostrami miłosierdzia a Florence Nightingale oraz charakterystykę trudnej współpracy sióstr z lekarzami wojskowymi i sanitariuszami znaleźć można w: The Crimean Journals of the Sisters of Mercy 1854-56 [online], ed. M. Luddy, Dublin 2004, p. 260, [Dostęp: 16.01.2018]. Dostępny w World Wide Web: <https://goo.gl/VZKLWd>.

13 Florence Nightingale (1820-1910). Urodziła się w bogatej arystokratycznej rodzinie. Wybitna brytyjska działaczka społeczna, publicystka i przede wszystkim pielęgniarka. Twórczyni nowoczesnego pielęgniarstwa i reformator opieki medycznej. Jako pierwsza dokonała systemowego rozróżnienia pomiędzy wiedzą medyczną a wiedza pielęgniarska. Była autorka pierwszego na świecie podręcznika $z$ dziedziny pielęgniarstwa (Notes on Nursing: What Nursing Is, What Nursing is Not, London 1859). W 1860 r. założyła druga na świecie świecką zawodowa szkołę pielęgniarską (The Nightingale Training School), w której realizowano jej autorski program nauczania. Jej zasługa jest zdefiniowanie metod i sposobów pielęgnacji chorych i poszkodowanych. Była ekspertem armii brytyjskiej ds. wojskowej służby pielęgniarskiej. W 1907 r. jako pierwsza kobieta otrzymała brytyjski Order Zasługi. W 1912 r. Międzynarodowy Komitet Czerwonego Krzyża ustanowił Medal Florence Nightingale będący prestiżowym odznaczeniem przyznawanym zasłużonym pielęgniarkom $z$ całego świata.

14 Elizabeth Fry (1780-1845). Należała do jednej z grup Religijnego Towarzystwa Przyjaciół (tzw. kwakrów), tj. nurtu pobożnościowego w protestantyzmie, odwołującego się do ideałów purytanizmu. Jej inicjatywy społeczne miały podłoże religijne. W 1840 r. dzięki jej staraniom powstał londyński Instytut Pielęgniarek. Jego absolwentki przechodziły regularne szkolenie w instytucjach medycznych.

15 Mary Jane Seacole (1805-1881). Brytyjska pielęgniarka, opiekunka chorych i rannych żołnierzy w czasie wojny krymskiej. Pochodziła $z$ mieszanej rasowo rodziny. Matka Mary Seacole była czarnoskórą kobietą, a ojciec szkockim oficerem służącym na Jamajce. W 1854 r. Mary przybyła do Anglii, by się przyłączyć do grupy sióstr miłosierdzia kierowanej przez Florence Nightingale, ale nie mogła być przyjęta z powodu koloru skóry. Dlatego popłynęła na Krym za własne pieniądze i jako świecka wolontariuszka pomagała rannym i chorym żołnierzom.

16 Reakcje lekarzy wojskowych na obecność sióstr miłosierdzia w szpitalach polowych były zróżnicowane po obu stronach frontu. Obok entuzjastów takich jak Mikołaj Pirogow było też wielu, którzy $z$ trudem godzili się $z$ obecnością wykwalifikowanego personelu kobiecego w szpitalnych salach i namiotach. Zmienili zdanie, gdy się zorientowali, że dzięki pielęgniarkom poprawie uległ fatalny stan sanitarny szpitali polowych, zrozumieli też, że 
czątkowali w okresie wojny krymskiej proces rozwoju nowoczesnej medycyny zaplecza pola walki.

\section{Zaangażowanie kobiet $\mathrm{w}$ opiekę pielęgniarską i pomoc humanitarną dla żołnierzy $\mathrm{z}$ armii Trójprzymierza przebywających w niewoli rosyjskiej}

Wielka Wojna $z$ racji swej powszechności i wykorzystywania na frontach nowoczesnego uzbrojenia przyniosła ze soba nie tylko więcej niż kiedykolwiek wcześniej ofiar śmiertelnych, lecz także niespotykana dotą liczbę rannych i chorych żołnierzy. Do niesienia im pomocy konieczne więc było pozyskanie odpowiednio wielu lekarzy i pielęgniarek. Dokładna liczba tych ostatnich do dziś nie jest ustalona. Dysponujemy jedynie szacunkowymi danymi, $z$ których wynika, że mogło ich być nawet kilkadziesiąt tysięcy ${ }^{17}$. Ponadto Wielka Wojna była konfliktem zbrojnym, który wymagał zaangażowania kobiet zarówno przy ratowaniu rannych $z$ pola walki i przy ich pielęgnacji w przyfrontowych szpitalach polowych, jak również wyznaczył im nową rolę, jaką stała się opieka nad będącymi w złej kondycji milionami jeńców wojennych. Pomoc wziętym do niewoli była konieczna szczególnie za linia frontu wschodniego. Wynikało to nie tylko $z$ ich liczebności i uciążliwości klimatu ${ }^{18}$, lecz także $z$ inercji „urzędowej Rosji" w sferze humanitarnej ${ }^{19}$.

W okresie Wielkiej Wojny do niewoli rosyjskiej dostało się od 2,2 do 2,5 mln jeńców $z$ armii państw centralnych ${ }^{20}$. Jeńcami zostali w więk-

ranni żołnierze umierają nie tylko $z$ powodu obrażeń, lecz także na skutek szoku pourazowego, że potrzebują zarówno leczenia, jak i opieki.

17 Ch. Hämmerle, Heimat/Front. Geschlechtergeschichte/n des Ersten Weltkriegs in Österreich-Ungarn, Wien 2014, s. 279.

18 Zdrowiu, a nawet życiu jeńców zagrażały zwłaszcza za Uralem wielomiesięczne mroźne zimy, w Turkiestanie zaś ekstremalne upały w miesiącach letnich.

19 Instytucje państwa rosyjskiego nie były przygotowane organizacyjnie i materialnie, a sami urzędnicy pod względem mentalnym, by sprostać wyzwaniom, jakie postawiły przed nimi milionowe rzesze jeńców. Instytucjonalna bierność prowadziła m.in. do ignorowania zagrożeń epidemiologicznych, jak też potęgowania trudności zaopatrzeniowych w obozach jenieckich.

20 Sibirskaja sovietskaja encyklopiedija, t. 1, red. M. Azadovskij i dr., Moskva 1929, s. 517 (èlektronnyj resurs) - podaje, że do niewoli w Rosji trafiło 2104146 żołnierzy i oficerów austro-węgierskich. Liczbę jeńców na poziomie 2,2-2,3 mln szacują: E. Brändström, Unter Kriegsgegangenen in Rusland und Sibirien (1914-1920) [online], Berlin 1922, s. 8, [Dostęp: 16.01.2018]. Dostępny w World Wide Web: <https://goo.gl/kC4gsh>; Internacionalisty. Učastie trudâŝčihsâ stran central'noj i jûgovostočnoj Evropy $v$ bor'be za vlast' Sovetov 
szości w latach 1914-1916. Trudy niewoli bardziej odczuwali oficerowie i żołnierze niemieccy oraz austriaccy ${ }^{21}$, a w nieco mniejszym stopniu ci wywodzaccy się $z$ tzw. przyjaznych nacji. Przed lutym 1917 r. jeńcy pochodzenia słowiańskiego traktowani byli stosunkowo przychylnie i mieli o wiele większą swobodę, np. w codziennych relacjach $\mathrm{z}$ rosyjską ludnością cywilną 22 .

Zgodnie z dyrektywami rosyjskiego Sztabu Generalnego z 1914 r. jeńcy niemieccy, austriaccy i węgierscy - w przeciwieństwie do słowiańskich i rumuńskich - uważani byli za bardziej niebezpiecznych. Konsekwencja wyodrębnienia obu kategorii przebywających w niewoli było kierowanie tych pierwszych do obozów zlokalizowanych na wschód od Uralu, a tych drugich do położonych w europejskiej części Rosji. Prócz zróżnicowania lokalizacyjnego obie kategorie obozów różniła też liczebność osadzonych. W tych zauralskich umieszczano średnio po 35 tys., a w tych europejskich od 2 do 10 tys. jeńców ${ }^{23}$. Konsekwencją tych różnic były odmienne warunki egzystencjalne i zakres opieki zdrowotnej - im bardziej na wschodzie zlokalizowany był dany obóz, tym były one gor$\mathrm{sze}^{24}$. O trudnych warunkach codziennego życia, niedostatkach zaprowiantowania, dolegliwościach zdrowotnych i o innych egzystencjalnych

v Rossii 1917-1920 gg. [online], red. A. Manusevič, Moskva 1987, k. 32-33, [Dostęp: 16.01.2018]. Dostępny w World Wide Web: <https://goo.gl/Tcehbk>; R. Nachtigal, Zur Anzahl der Kriegsgefangenen im Ersten Weltkrieg, „Militargeschichtliche Zeitschrift” 2008, No. 2, s. 345-384, DOI: https://doi.org/10.1524/mgzs.2008.67.2.345. Liczbę 2497378 jeńców, w tym 167082 wziętych do niewoli żołnierzy i oficerów niemieckich, podaje: Der Weltkampf um Ehre und Recht : die Erforschung des Krieges in seiner wahren Begebenheit, auf amtlichen Urkunden und Akten beruhend [online], red. M. Schwarte, Berlin 1919, s. 182, [Dostęp: 16.01.2018]. Dostępny w World Wide Web: <https://goo.gl/ZBbK2X>.

21 Wśród jeńców $z$ armii państw centralnych, którzy dostali się do niewoli rosyjskiej, Niemcy z II Rzeszy i Niemcy z Austro-Węgier stanowili łącznie od 24 do 28\% (zob. Internacionalisty. Učastie trudâŝ́čihsâ stran..., op. cit., k. 33).

${ }_{22}$ Rosjanie, pośród których toczyło się życie jeńców wojennych, w większości przypadków odnosili się do nich $z$ obojętnością. Obok tej dominującej postawy były nieraz pewne przejawy sympatii, jak też przypadki manifestowanej ostentacyjnie niechęci czy wręcz nienawiści. Te ostatnie były jednak odosobnione, podobnie jak inna skrajność, czyli obdarzanie jeńców przyjaźnią. Szerzej ten watek podejmuje: R. Nachtigal, Kriegsgefangene der Habsburgermonarchie in Russland, „Österreich in Geschichte und Literatur mit Geographie" 1996, Vol. 40, s. 248-262.

${ }^{23} \mathrm{Z}$ rosyjskich danych wynika, że 1 stycznia 1915 r. spośród 257 tys. jeńców za Ural trafiło 186 tys. (zob. Internacionalisty. Trudâščijsâ zarubiežnych stran - učastniki borby za wlast Sowietow, red. A. Manusevič, Moskva 1967, s. 16).

24 Internacionalisty, red. kollektiw awtorow, Moskva 1971, s. 69. 
niedogodnościach jeńcy szeroko się rozpisywali w korespondencji kierowanej do domów rodzinnych ${ }^{25}$.

Setki tysięcy żołnierzy niemieckich, austriackich i węgierskich, którzy dostali się do niewoli rosyjskiej przed wybuchem rewolucji lutowej, trafiło zgodnie $z$ rozdzielnikiem do obozów jenieckich rozlokowanych w większości na Syberii Zachodniej i Wschodniej, na Dalekim Wschodzie, w północnym Kazachstanie oraz w Turkiestanie ${ }^{26}$. Wielu $z$ nich $z$ racji na odniesione w trakcie walk frontowych rany lub ze względu na choroby, których się nabawili w niewoli, wymagało pomocy i opieki medycznej. Rosjanie mimo zobowiazań prawno-międzynarodowych nie byli w stanie im takiej pomocy zapewnić w wystarczającym stopniu. Jeńcy w ogarniętej wojennym chaosem Rosji mogli przede wszystkim liczyć na pomoc humanitarna ze strony czerwonokrzyskich wolontariuszek i wolontariuszy z państw neutralnych.

Początkowo nic nie wskazywało na to, że osadzonym w rosyjskich obozach jenieckich może grozić katastrofa humanitarna. Państwo rosyjskie było jednym z sygnatariuszy IV Konwencji Haskiej z 1907 r. poświęconej prawom i zwyczajom wojny lądowej ${ }^{27}$. W duchu tego prawa 14 października 1914 r. wydane zostały pierwsze ogólne przepisy rosyjskie dotyczące jeńców wojennych. Gwarantowały im traktowanie na równi $z$ własnymi żołnierzami w zakresie zakwaterowania, wyżywienia i leczenia. Jednak już w lutym 1915 r. $z$ racji na trudna sytuację w kraju zmodyfikowano pierwotne rozporzadzenia ${ }^{28}$. Wprowadzone zmiany doprowadziły do znacznego pogorszenia statusu jeńców $z$ armii państw

\footnotetext{
${ }_{25}$ Szerzej o tym specyficznym źródle wiedzy historycznej i możliwych do pozyskania zeń informacjach pisze: A. Rachamimov, Alltagssorgen und politische Erwartungen. Eine Analyse von Kriegsgefangenenkorrespondenzen in den Beständen des Österreichischen Staatsarchivs, „Zeitgeschichte” 1998, No. 25, s. 350-351. Tenże autor, opierając się m.in. na jenieckich źródłach epistolarnych, opublikował interesująca książkę, która w znacznej części odnosi się do gehenny żołnierzy austro-węgierskich w niewoli rosyjskiej: Idem, POWs and the Great War. Captivity on the Eastern Front, Oxford 2002, p. 87-132.

26 Przykładowo w 1914 r. w Turkiestanie osadzono około 150 tys. jeńców z armii austro-węgierskiej. Ulokowano ich w obozach i opuszczonych obiektach koszarowych (zob. szerzej: Ėtničeskij atlas Uzbekistana [online], red. A. Ilkhamov, [Dostęp: 26.01.2018]. Dostępny w World Wide Web: <https://goo.gl/toaCKY>). O specyfice codziennego funkcjonowania jeńców w obozach turkiestańskich mowa jest w zbiorze wspomnień: Polacy $w$ Turkiestanie $w$ okresie wojny światowej, red. S. Żelazowski [et al.], Warszawa 1931, passim; por. K.W. Juszczak, Szlakiem jeńców z Turkiestanu do niepodległej Polski, Poznań 1928, passim.

27 Treść konwencji zob. https://pl.wikisource.org/wiki/Konwencja_haska_IV_(1907).

28 E. Brändström, op. cit., s. 7.
} 
centralnych. Ich sytuacja uległa zmianie nie tylko wskutek wprowadzenia bardziej restrykcyjnych przepisów wykonawczych do IV Konwencji Haskiej $^{29}$, lecz także wynikała $z$ postępującego rozprężenia rosyjskiego aparatu państwowego.

Mimo że Ministerstwo Wojny w Piotrogrodzie miało w swojej strukturze Wydział Jeńców Wojennych, to z początkiem 1915 r. nie był on już w stanie wymóc na komendantach obozów wykonywania kierowanych doń dyspozycji. Tym bardziej że często były one z przyczyn obiektywnych niewykonalne. Zwłaszcza gdy szwankowało zaopatrzenie nie tylko w medykamenty, lecz także w żywność czy środki higieny - nie sposób było przestrzegać regulaminów. Dla podkomendnych nigdy nie było nic bardziej demoralizującego, jak wydawanie przez przełożonych poleceń niewykonalnych (szczególnie w czasie wojny). Zawsze i wszędzie prowadziło to do wymuszonej okolicznościami niesubordynacji tych „na dole” i utraty kontroli przez tych „na górze”.

Jak te uwarunkowania wewnatrzrosyjskie przekładały się na codzienne życie milionów jeńców wojennych $z$ armii państw centralnych w Rosji? $Z$ dostępnych przekazów wynika, że najcięższe konsekwencje ponosili ci, którzy do niewoli dostali się jako ranni lub zachorowali w czasie transportu. Rosyjski personel medyczny, pod którego opiekę trafiali, nie zawsze traktował ich w odpowiedni sposób. Było to efektem wywołanej i podsycanej przez rosyjska prasę niechęci wobec germańskich najeźdźców ${ }^{30}$. Czasami przejawiała się ona w postaci zwykłej złośliwości. W raportach Szwedzkiego i Duńskiego Czerwonego Krzyża odnotowano np. przypadek przewożenia grupy chorych jeńców pomiędzy dziewięcioma szpitalami w Moskwie. Po tygodniowej wędrówce trafili oni w końcu do tego właściwego, w którym ostatecznie udzielono im stosownej pomocy $^{31}$. O wiele bardziej drastyczna sytuacja miała miejsce, gdy grupę rannych wymagajacych zaopatrzenia ortopedycznego skierowano do budynków punktu etapowego, a nie do położonego pół kilometra dalej

\footnotetext{
${ }^{29}$ Chodziło przede wszystkim o przepisy wykonawcze do art. 5, 6 i 7 z rozdziału II „O jeńcach wojennych".

30 Nie wszyscy tę niechęć manifestowali. Poza starą i nową stolicą w Rosji gubernialnej zjawisko to występowało w ograniczonym zakresie. Pisze o tym: R. Dyboski, Siedem lat $w$ Rosji i na Syberji (1915-1921). Przygody i wrażenia, Warszawa 1922, s. 42-62; por. J. Zemła, W obozach jeńców wojennych na Syberji, Warszawa 1934, s. 165.

${ }^{31}$ Der Weltkampf um Ehre und Recht..., op. cit., s. 184.
} 
szpitala. Część rannych, nie widząc dla siebie innego ratunku, przeczołgała się po śniegu $500 \mathrm{~m}$ do izby przyjęć, gdzie udzielono im pomocy ${ }^{32}$.

Nie lepiej sytuacja wyglądała, gdy jeńcy docierali do miejsc osadzenia. Za Uralem Rosjanie nie byli w stanie zapewnić niektórym jeńcom nawet przysłowiowego dachu nad głową. Niedobór środków finansowych na rozbudowę sieci obozowej i wymuszone tą okolicznością rozmieszczenie jeńców $\mathrm{w}$ adaptowanych naprędce zabudowaniach miejskich w niedługim czasie nieomal nie wywołały katastrofy humanitarnej. W Tobolsku, Nowomikołajewsku i Tiumeniu już jesienią 1914 r. odnotowano pierwsze przypadki zachorowań na tyfus, szkarlatynę i czerwonkę ${ }^{33}$.

Niemcy nadbałtyccy, nadwołżańscy i ci mieszkający w rosyjskich miastach, w których - jak w Moskwie - były punkty etapowe (przesyłowe) dla jeńców transportowanych $z$ rejonów przyfrontowych do obozów w głębi Rosji, podejmowali próby niesienia pomocy rodakom. W kilku miejscowościach powstały nawet stowarzyszenia dobroczynne, a ich niemieccy członkowie zdołali zorganizować służby ratunkowe w szpitalach i wzdłuż tras, którymi przemieszczano jeńców. Oprócz Moskwy działały one np. w Wiatce i Ufie ${ }^{34}$. Po odstapieniu przez Ministerstwo Wojny w 1915 r. od pełnego przestrzegania IV Konwencji Haskiej wszystkie te oddolne inicjatywy upadły. Wobec łamiących zakaz niesienia zorganizowanej pomocy stosowano kary. Władze wojskowe i gubernialne tolerowały wyłącznie oddolna pomoc indywidualną. Ta jednak $z$ racji na swoje ograniczenia nie pozwalała na skuteczne zaspokojenie potrzeb jeńców $z$ armii państw centralnych.

W zaistniałej sytuacji jedyną instytucja, jaka mogła nieść pomoc osadzonym w obozach jenieckich i transportowanym do nich, był Czerwony Krzyż. Ze względów politycznych zadania tego nie mogły się podjąć bezpośrednio jego struktury rosyjskie ani tym bardziej niemieckie czy austro-węgierskie. Do niesienia pomocy jeńcom Rosjanie dopuszczali wyłącznie organizacje czerwonokrzyskie $z$ państw neutralnych. Zadania tego podjęły się szwedzkie i duńskie przedstawicielstwa Czerwonego

\footnotetext{
32 Ibidem.

33 Mimo zapobiegliwości personelu medycznego jeszcze przed 1 kwietnia 1915 r. wśród 135 tys. jeńców rozlokowanych na terenie Omskiego Okręu Wojskowego odnotowano 518 przypadków tyfusu, 124 duru i 177 dyzenterii (zob. „Wiestnik Omskogo Gorodskogo Obszczestwiennogo Uprawlenija” 1915, No. 6/7, s. 41).

34 Der Weltkampf um Ehre und Recht..., op. cit., s. 185.
} 
Krzyża, którym Berlin i Wiedeń - za przyzwoleniem Piotrogrodu - powierzyły los swoich żołnierzy w rosyjskiej niewoli.

Dzięki zaangażowaniu Duńskiego Czerwonego Krzyża, który $z$ jednej strony porozumiał się $z$ rosyjską cesarzowa wdową Marią Fiodorowna, a $z$ drugiej $z$ berlińskimi i wiedeńskimi kręgami dworskimi, już w kwietniu 1915 r. udało się przygotować wizyty delegacji Międzynarodowego Komitetu Czerwonego Krzyża (MKCK) w obozach dla jeńców rosyjskich na terenie państw centralnych i w obozach dla jeńców $z$ tych państw na terenie Rosji ${ }^{35}$.

Jesienią 1915 r. do państwa carów przybyła delegacja MKCK, którą współtworzyło sześć grup wizytujących. Trzy z nich złożone były $z$ delegatek Austriackiego i trzy z Niemieckiego Czerwonego Krzyża ${ }^{36}$. W każdym z sześciu zespołów były przedstawicielki Misji Duńskiego lub Szwedzkiego Czerwonego Krzyża w Rosji oraz towarzyszący im rosyjscy oficerowie-tłumacze. Wyjazd delegacji MKCK był koordynowany przez duńskiego lekarza Thorvalda Madsena, który jako neutralny obserwator reprezentował genewska centralę organizacji ${ }^{37}$.

Po konsultacjach w Wydziale Jeńców Wojennych rosyjskiego Ministerstwa Wojny delegacje MKCK podjęły na początku września $1915 \mathrm{r}$. czynności sprawdzające. W jednej $z$ tych grup znalazła się przełożona generalna sióstr Niemieckiego Czerwonego Krzyża - Alexandrine von Üxküll-Gyllenband ${ }^{38}$. Jako jedyna w gronie wizytujących rosyjskie obozy jenieckie miała już za sobą tego typu doświadczenie. Kilka miesięcy

35 R. Nachtigal, Die dänisch-österreichisch-ungarischen Rotkreuzdelegierten in Russland 1915-1918. Die Visitationen der Kriegsgefangenen der Mittelmächte durch Fürsorgeschwestern des österreichischen und ungarischen Roten Kreuzes, „Zeitgeschichte” 1998, No. 25, s. 366-374.

${ }^{36}$ W gronie niemieckich sióstr znalazły się: Alexandrine von Üxküll-Gyllenband, Erika von Passow i Magdalene von Walsleben, a w grupie austro-węgierskich: Käthe von Mihalotzy, Anna Revertera i Ilona von Rosty (szerzej zob. A. Rachamimov, POWs and the Great War..., op. cit., s. 172-173).

37 Thorvald Madsen (1870-1957). Duński lekarz i bakteriolog. W latach 1921-1937 przewodniczacy Komitetu Zdrowia Ligi Narodów (odpowiednik WHO). Podczas I wojny światowej był mocno zaangażowany w działalność humanitarna na rzecz jeńców wojennych (szerzej o tej postaci pisze: A. Hardy, Actions not Words. Thorvald Madsen, Denmark, and International Health 1902-1939, DOI: http://dx.doi.org/10.3726/978-3-653-05156-8 [w:] Of Medicine and Men. Biographies and Ideas in European Social Medicine between the World Wars [online], ed. I. Borowy, A. Hardy, Frankfurt a. M. 2008, s. 127-144, [Dostęp: 26.01.2018]. Dostępny w World Wide Web: <https://goo.gl/WNxGaE>).

38 Alexandrine von Üxküll-Gyllenband (1873-1963). Była siostrą Karoline von Stauffenberg, tj. matki pułkownika Klausa Schenk von Stauffenberga, który dokonał nieudanego zamachu na życie Hitlera 20 lipca 1944 r. 
wcześniej była w grupie sióstr czerwonokrzyskich kontrolujących obozy na terenie Francji. W jej ocenie porównanie jednych i drugich wypadło zdecydowanie na niekorzyść tych za frontem wschodnim. Równie negatywne opinie formułowała inna niemiecka delegatka Magdalene Walsleben $^{39}$. Do podobnych konkluzji doszły także delegatki austro-węgierskie Anna Revertera ${ }^{40}$ i Käthe Mihalotzy ${ }^{41}$. $Z$ wszystkich tych relacji wynika, że sytuacja jeńców niemieckich i austro-węgierskich w Rosji była tragiczna. Katastrofa humanitarna groziła zwłaszcza obozom syberyjskim ${ }^{42} . Z$ racji na narzucone ograniczenie czasowe pobytu niemieckich i austro-węgierskich sióstr w poszczególnych obozach do maksymalnie dwóch dni mogły one udzielić osadzonym w nich zaledwie doraźnej pomocy. Rozdzieliły więc między jeńców znaczne kwoty pieniędzy i uzyskały zapewnienie od Rosjan, że podejma starania, by wyeliminować najbardziej drastyczne nadużycia zaobserwowane w obozach. Podczas tak krótkich wizyt nie można było jednak odczuwalnie poprawić położenia jeńców w żadnym z obozów. W sumie przed końcem 1915 r. sześć delegacji odwiedziło zaledwie 123 obozy, w których przebywało 272919 jeńców austro-węgierskich i 47953 niemieckich ${ }^{43}$.

Sytuacji nie mogło poprawić przybycie wiosna 1916 r. dziesięciu kolejnych sióstr czerwonokrzyskich z Niemiec i Austro-Węgier (po pięć $z$ każdego kraju $)^{44}$. Tylko zaangażowanie do codziennej opieki odpowiednio

\footnotetext{
${ }_{39}$ M. Walsleben (Steinaecker), Die deutsche Schwester in Sibirien: Aufzeichnungen von einer Reise durch die sibirischen Gefangenenlager vom Ural bis Wladiwostok [online], Berlin 1919, s. 28 i n, [Dostęp: 26.01.2018]. Dostępny w World Wide Web: <https://goo.gl/ AGj3vZ>.

40 Als Österreichische Rotkreuzschwester in Russland. Tagebuch von Gräfin Anna Revertera, „Süddeutsche Monatshefte” 1923, September, s. 252-281. Por. A. Revertera, Als Rotkreuzschwester in Russland und Sibirien [w:] In Feindeshand : die Gefangenschaft im Weltkriege in Einzeldarstellungen, ed. Hans Weiland, Leopold Kern, Wien 1931, Band 2, s. 245-251.

${ }^{41}$ K. Mihalotzy, Eine Reise durch Kriegsgefangenenlager in Russland und Turkestan [w:] Ibidem, s. 251-255.

${ }_{42}$ Bericht der Dänischen Roten-Kreuz-Delegation zum Besuch der deutschen Kriegsgefangenenlager in Russland, der deutschen Schwester, Oberin Gräfin Alexandrine Üxküll-Gyllenband und des Dänischen Obersten G.C. Muus [w:] Völkerrechtswidrige Behandlung der deutschen Kriegsgefangenen in Russland, Berlin 1918, Band 2, Anlage 413.

${ }^{43}$ Ch. Hadeln, Deutsche Frauen, Deutsche Treue 1914-1933. Ein Ehrenbuch der deutschen Frau, Berlin 1935, s. 27-31.

${ }^{44}$ Wśród nich były odpowiednio: Emma von Bunsen, Elisabeth von Gagern, Mathilde Horn, Annit Rothe, Anne-Marie Wenzel oraz Magda Cebrian, Cunigunde von Croy-Dülmen, Andorine von Huszár, Nora Kinsky, Pauline von Stubenberg-Palffy (szerzej zob. A. Rachamimov, POWs and the Great War..., op. cit., s. 179-180).
} 
licznej grupy czerwonokrzyskich sióstr z państw neutralnych stwarzało szansę na trwałe zmiany na lepsze.

Dla powodzenia misji niesienia pomocy jeńcom w Rosji kluczową decyzją okazało się zaangażowanie grupy kilkudziesięciu szwedzkich sióstr czerwonokrzyskich zamieszkałych na terenie państwa carów. Wśród nich były Elsa Brändström ${ }^{45}$, towarzysząca Alexandrine Üxküll-Gyllenband w czasie wizytacji obozów syberyjskich, i jej najbliższa wspólpracownica Ethel von Heidenstam ${ }^{46}$. Wzorem dla nich obu i dla pozostałych wolontariuszek Czerwonego Krzyża w targanej wojną Europie stała się w tym czasie brytyjska pielęgniarka Edith Cavell, która niosąc pomoc jeńcom, nie bała się zaryzykować i poświęcić własnego życia ${ }^{47}$.

Pracujące w obozach jenieckich w Rosji czerwonokrzyskie siostry wszystkie bez wyjątku poszły tą drogą. Niektóre $z$ nich wzorem Edith Cavell miały zapłacić za swoje poświęcenie najwyższą cenę, umierając $z$ powodu chorób zakaźnych, czy - jak Erika Passow - ginąc z ręki rosyjskich odpowiedników tych, którym niosły pomoc ${ }^{48}$.

Część czerwonokrzyskich sióstr, zarówno tych z państw neutralnych, jak i te $z$ państw centralnych po zakończeniu wojny opublikowało

\footnotetext{
45 Elsa Brändström (1888-1948). Urodziła się w Petersburgu w rodzinie wieloletniego attaché wojskowego szwedzkiej ambasady. Rodzice Per Henrik Edvard i Anna Wilhelmina Brändström zapewnili jej staranne wykształcenie w sztokholmskim seminarium nauczycielskim. Zapisała się w historii jako „Anioł Syberyjski”, organizując na niespotykaną wcześniej skalę pomoc jeńcom wojennym. Skupiła się na opiece nad najbardziej doświadczonymi w rosyjskiej niewoli niemieckimi i austriackimi żołnierzami osadzonymi w obozach syberyjskich, rozsianych od Uralu aż po Pacyfik.

46 Ethel Mabyn Thornton (1881-1975). Jej pochodzący z Anglii rodzice Bateman i Emmie Thorton byli właścicielami dużego młyna pod Petersburgiem. Tam też mieszkali i w stolicy Rosji urodziła się ich córka Ethel Mabyn. W 1904 r. poślubiła szwedzkiego dyplomatę Carla Gerharda von Heidenstama, oddelegowanego do pracy w ambasadzie tego skandynawskiego kraju w Petersburgu.

47 Edith Louisa Cavell (1865-1915). Brytyjska pielęgniarka, której bohaterska i tragiczna śmierć przyniosła jej miano męczennicy okresu I wojny światowej. Była przełożona pielęgniarek szpitala wojskowego w Brukseli. Pozostała na swoim stanowisku także po wkroczeniu wojsk niemieckich. Za ukrywanie rannych żołnierzy alianckich we własnym domu i pomoc w przedostawaniu się do Holandii została przez Niemców aresztowana i postawiona przed sądem wojennym, który skazał ją na śmierć przez rozstrzelanie. Szerzej o tej postaci pisze: E. Grey, Friend Within the Gates. The Story of Nurse Edith Cavell [online], Boston 1961, [Dostęp: 17.01.2018]. Dostępny w World Wide Web: <https://goo. gl/ck5YR4>.

48 Została porwana, zgwałcona i zamordowana w maju 1919 r. przez zdemoralizowanych wojną i rewolucją „sołdatów”.
} 
wspomnienia ze swojej misji w Rosji ${ }^{49}$. Dowiadujemy się z nich, niejako z pierwszej ręki, jakie wyzwania stawały na co dzień przed wolontariuszkami, na ile były one w stanie im sprostać i przede wszystkim, jaka tragedią dla milionów jeńców była rosyjska niewola. Autorki ukazały głównie wymiar egzystencjalny obozowej traumy. Niektóre $z$ nich podjęły też problem skutków psychologicznych wieloletniej izolacji jeńców. Najmniej wyeksponowały watek przemian światopoglądowych w środowisku jenieckim, jakie się w nim dokonały pod wpływem indoktrynacji bolszewickiej ${ }^{50}$. Wojna na froncie wschodnim, niewola w Rosji, a finalnie chaos rewolucyjny w tym kraju doprowadziły miliony mężczyzn z Europy Środkowej nie tylko do okaleczenia fizycznego, psychicznego i moralnego, lecz także często do radykalizacji poglądów. Tysiące spośród nich z czasem uległo bolszewizacji. U wziętych do niewoli na frontach zachodnim i włoskim tak daleko posuniętej radykalizacji i na taką skalę nie było ${ }^{51}$. We francuskich i włoskich obozach jenieckich największą popularnością cieszyły się idee pacyfistyczne. Podobnie było w rosyjskich obozach, $z$ tą

${ }^{49}$ Obok cytowanych powyżej publikacji E. Brändström, M. Walsleben, A. Revertera i K. Mihalotzy interesujace wspomnienia pozostawiły: E. Gagern, Nür Frauen. Die Ordensidee Maria Wards, München 1949; N. Kinsky, Russisches Tagebuch 1916-1918, Stuttgart 1976; A. Üxküll-Gyllenband, Aus einem Schwesternleben, Stuttgart 1956; A. Wenzel, Deutsche Kraft in Fesseln. Fünf Jahre deutscher Schwesterndienst in Sibirien (1916-1927), Potsdam 1931.

50 Szerzej na temat rewolucjonizowania przez bolszewików jeńców $z$ armii państw centralnych i światopogladowych konsekwencjach tych działań dla społeczeństw europejskich piszą: V. Moritz, H. Leidinger, Gefangenschaft, Revolution, Heimkehr. Die Bedeutung der Kriegsgefangenenproblematik für die Geschichte des Kommunismus in Mittel- und Osteuropa 1917-1920 [online], Wien 2003, [Dostęp: 26.01.2018]. Dostępny w World Wide Web: <https://goo.gl/HQN5su>; zob. też: T. Gantert, Deutsche und österreichische Kriegsgefangene des Ersten Weltkriegs in russisch-sowjetischem Gewahrsam [online]. Dissertation Institut für Geschichte der Medizin der Ruprecht-Karls-Universität Heidelberg. Hauptberichterstatter: prof. dr Wolfgang U. Eckart, 2008, Heidelberg 2009, [Dostęp: 26.01.2018]. Dostępny w World Wide Web: <https://goo.gl/8RKRhm>.

51 Z. Karpus, Obozy jeńców wojennych $z$ państw Ententy na ziemiach polskich pod panowaniem pruskim (1914-1918) [w:] Społeczeństwo polskie na ziemiach pod panowaniem pruskim w okresie I wojny światowej, red. M. Wojciechowski, Torun 1996, s. 149-162; J. Bączyk, Armie za drutami. Jeńcy wojenni na terenie prowincji poznańskiej (1914-1918), Poznań 2015, passim; Z. Karpus, Jeńcy rosyjscy i bolszewiccy $w$ Tucholi (1914-1922) [w:] Tuchola: obóz jeńców i internowanych 1914-1923, t. 1, cz. 3: Warunki życia jeńców $i$ internowanych, red. Z. Karpus, W. Rezmer, Torun 2007, s. 43-48; J. Snopko, Z problemów opieki nad polskimi jeńcami w obozach państw centralnych w latach pierwszej wojny światowej (1914-1918) [w:] Z dziejów Rosji i Polski w XX wieku. Księga dedykowana prof. Richardowi Pipesowi, red. H. Kocój, R. Małek, M. Szczerbiński, Gorzów Wielkopolski 2006, s. 193-203. 
jednak różnica, że równolegle tysiące zwolenników zyskała tam idea powszechnej rewolucji lansowana przez bolszewików.

Jak do tego doszło? Czy w przypadku jeńców $z$ armii państw centralnych byt określił (zmienił) świadomość? Czy ich podatność na radykalizację mogła być konsekwencja złego traktowania w niewoli? Już jesienią 1914 r. Elsa Brändström miała okazję się przekonać, jak trudnej sytuacji egzystencjalnej doświadczali niemieccy i austro-węgierscy jeńcy w Rosji ${ }^{52}$. Miało to miejsce w trakcie kursu pielęgniarskiego dla „dam z wyższych sfer", na który się zgłosiła, by móc podjąć służbę pielęgniarską w armii rosyjskiej. Szkolac się, a następnie pracujacc w szpitalu Mikołajowskim w Piotrogrodzie, była świadkiem gehenny około 4 tys. ciężko rannych niemieckich oficerów i żołnierzy wziętych do niewoli w Prusach Wschodnich i Królestwie Polskim, którzy na przestrzeni kilku miesięcy przewinęli się przez ten szpital. W przeciwieństwie do małych szpitali gubernialnych na bliskim zapleczu frontu, jak np. w Suwałkach, o którym wiemy $z$ relacji czerwonokrzyskiej siostry z Kongresówki Laury de Gozdawa Turczynowicz ${ }^{53}$, w tych stołecznych rannych jeńców raczej przetrzymywano niż leczono.

Pod wpływem tego, co Elsa zaobserwowała w szpitalu Mikołajowskim, wspólnie ze swoją współpracownica Ethel Heidenstam zdecydowała się zaangażować $\mathrm{w}$ niesienie pomocy pielęgniarskiej jeńcom także poza Piotrogrodem. Po uzyskaniu stosownych zezwoleń wyruszyły jako wolontariuszki do obozów jenieckich rozsianych od Uralu po Pacyfik ${ }^{54}$. Ich rolą oprócz niesienia pomocy jeńcom było także uwrażliwianie Rosjan (elit i nizin społecznych) na los przetrzymywanych w niewoli żołnierzy, niezależnie od ich narodowości, a więc i na los Niemców i Austriaków.

\footnotetext{
52 Na przełomie lat 1914/1915 zakres opieki nad rannymi jeńcami niemieckimi niewiele odbiegał od tej, która otaczano rannych rosyjskich żołnierzy. Dokumentuje to w swoich wspomnieniach czerwonokrzyska siostra: L. de Gozdawa Turczynowicz, When the Prussians came to Poland; the experiences of an American woman during the German invasion [online], New York 1916, [Dostęp: 26.01.2018]. Dostępny w World Wide Web: <https:// goo.gl/Vx21xD>. Na ich podstawie istotne ustalenia poczyniła: A. Drozdowska, Kobiety z ziem Królestwa Polskiego i Obwodu Białostockiego podczas pierwszej wojny światowej, praca mag., Uniwersytet w Białymstoku, Białystok 2017, s. 27 [mps]; por. Eadem, Kobiety a działalność Czerwonego Krzyża na ziemiach polskich zaboru rosyjskiego $w$ latach 1914-1916 na podstawie wspomnień lekarza Czerwonego Krzyża oraz Laury de Turczynowicz, „Czasopismo Naukowe Instytutu Studiów Kobiecych” 2017, nr 1 (2), s. 73-91, DOI 10.15290/cnisk.2017.01.02.04.

53 L. de Gozdawa Turczynowicz, op. cit., s. 18-22.

54 Niosąc pomoc jeńcom, przemierzyły cała Syberię od Uralu aż po Pacyfik.
} 
W drodze się przekonały, że ryzyko śmierci rannych jeńców $\mathrm{w}$ trakcie transportu było jeszcze większe niż to występujące w stołecznych szpitalach. W Moskwie obie wolontariuszki dowiedziały się o tragedii, do której doszło, gdy skład przewożący tureckich jeńców ${ }^{55}$ skierowano na dworcową bocznicę i pozostawiono ich tam na noc w zamkniętych wagonach. Dowódca oddziału eskortującego zamiast odstawić Turków do budynków punktu przesyłowego uznał, że mimo siarczystego mrozu zdołaja przetrwać noc w wagonach. Liczył naiwnie, że przeżyja, ogrzewając się ciepłem własnych ciał. Rankiem, gdy otwarto wagony, okazało się, że wielu jeńców nie żyje. W niektórych wagonach zamarzli wszyscy. Ich poprzytulane do siebie, zamarznięte ciała tworzyły nierozerwalna masę. Usuwanie ich wymagało użycia ostrych narzędzi, by oddzielić jednych od drugich. To, co się wydarzyło na moskiewskim dworcu, nie było ewenementem. Obie wolontariuszki mogły się o tym niebawem przekonać także w Penzie, gdzie $z$ powodu nieodpowiedzialności tych „na górze” i znieczulicy tych „na dole” doszło do podobnej sytuacji ${ }^{56}$.

Niekompetencja i wywołany wojna chaos komunikacyjny sprawiły, że pociagi przewożące jeńców z zaplecza frontu do obozów zlokalizowanych na terenie Syberii Zachodniej i Wschodniej, na Dalekim Wschodzie, w północnym Kazachstanie oraz w Turkiestanie przetrzymywane były nie tylko na dworcowych bocznicach, lecz także dosłownie w szczerym polu. Nieraz się zdarzało, że stały tak przez tydzień czy nawet dwa tygodnie. W tym czasie ranni i chorzy jeńcy byli narażeni na głód i mróz, a co gorsza, nie mogli liczyć zarówno na leczenie, jak i nawet na opiekę

\footnotetext{
55 O sytuacji jeńców tureckich w niewoli rosyjskiej w latach Wielkiej Wojny i rewolucji rosyjskich historiografia europejska praktycznie milczy. Tym bardziej warta jest odnotowania publikacja przetłumaczona $z$ języka tureckiego na angielski. Sa to wspomnienia porucznika armii tureckiej Mehmeta Arifa Ölçena, który w lutym 1916 r. dostał się do niewoli rosyjskiej. Treściwy wstęp i podsumowanie napisane przez Ali Nejat Ölçena (syna autora wspomnień), podobnie jak przekład historyka Gary'ego Leisera, pozwalaja zyskać orientację nt. tego mało nam znanego epizodu Wielkiej Wojny. Dla współczesnego badacza niemniej istotny jest też fakt, że publikacja ta jest dostępna w sieci (zob. M.A. Ölçen, Vetluga memoire. A Turkish prisoner of war in Russia 1916-1918 [online], transl. G. Leiser, Gainesville 1995, [Dostęp: 26.01.2018]. Dostępny w World Wide Web: <https://goo.gl/ $\mathrm{mF} 8 \mathrm{SpB}>$; zob. też bibliografia artykułu monograficznego: Y. Yanikdag, Ottoman Prisoners of War in Russia 1914-22 [online], „Journal of Contemporary History” 1999, Vol. 34, No. 1, p. 69-85, [Dostęp: 26.01.2018]. Dostępny w World Wide Web: <https://goo.gl/vZmHWv>. 56 H. Kessler, Tagebücher 1918-1937. Gesamtausgabe [online], (Kapitel 9. Inschrift: Berlin. 22 Februar 1926. Montag), [Dostęp: 26.01.2018]. Dostępny w World Wide Web: <https://goo.gl/j17J3m>.
} 
pielęgniarską ${ }^{57}$. Przedłużające się postoje pociagów lub ich brak skłaniały nieraz dowódców oddziałów eskortujacych do podejmowania decyzji, by ze zdrowych i lekko rannych jeńców formować kolumny marszowe i pieszo podążać w kierunku wyznaczonych miejsc osadzenia. Dziennie pokonywano około $30 \mathrm{~km}$. Taki marsz trwał tyle dni, ile pociag pozostawał unieruchomiony. Gdy po tygodniu czy dwóch wreszcie ruszał, to doganiał idących wzdłuż torowisk jeńców i po powtórnym ich załadunku transportował dalej na wschód ${ }^{58}$.

W 1915 r. Elsa Brändström i Ethel Heidenstam kontynuowały swoja humanitarna misję już jako siostry Szwedzkiego Czerwonego Krzyża. Sformalizowanie własnego statusu prócz tego, że zapewniało im prawno-międzynarodową ochronę, dawało też obu wolontariuszkom dostęp do tak potrzebnych w opiece nad jeńcami śodków materialnych, przede wszystkim leków i żywności. W praktyce obie panie $z$ dnia na dzień stały się koordynatorkami akcji humanitarnej prowadzonej przez Szwedzki Czerwony Krzyż w obozach dla jeńców niemieckich i austro-węgierskich na terenie Rosji. Od 1915 r. w niesienie pomocy jeńcom zaangażowanych było blisko osiemdziesiąt szwedzkich wolontariuszek i wolontariuszy ${ }^{59}$.

W swoich wspomnieniach Elsa Brändström wielokrotnie pisała, jakim przeżyciem dla niej i jej współpracownicy Ethel Heidenstam były wizyty w syberyjskich obozach jenieckich. Najtrudniejsze emocjonalnie zawsze były te pierwsze, gdy rozdzielały żywność, medykamenty i pieniądze jeńcom, którzy przez wiele miesięcy nie mogli liczyć na jakakolwiek pomoc. Stan zdrowia fizycznego i psychicznego większości z nich był tragiczny. Warunki egzystencjalne czasami wręcz nieludzkie. Normą było, że w pomieszczeniach przeznaczonych dla jeńców brakowało miejsc do spania. Konieczna była rotacja. Czy mogło być inaczej, skoro np. ośmiuset jeńców niemieckich ulokowano w pomieszczeniach koszarowych przeznaczonych dla pięciuset osób? Egzystując w takich warunkach, często przez wiele tygodni, a nawet miesięcy bez kąpieli, jeńcy narażeni byli na choroby zakaźne. Za rozprzestrzenianie się epidemii obwiniano rosyjskich lekarzy obozowych, którzy albo zbyt późno decydowali się na izolowanie pierwszych chorych, albo nakazywali izolowanie całych bara-

\footnotetext{
57 E. Brändström, op. cit., s. 69.

58 Ibidem, s. 9.

59 Ibidem, s. 76.
} 
ków ze zdrowymi jeńcami, w których pozostawiali pojedynczych chorych. W efekcie zarówno $z$ powodu braku gorliwości, jak i z jej nadmiaru chorowali i umierali ludzie. W pierwszym roku wojny ponad $80 \%$ niemieckich i austro-węgierskich jeńców dotkniętych zostało chorobami zakaźnymi ${ }^{60}$. Śmiertelność w niektórych obozach, tak jak np. w Nowonikołajewsku, przekraczała w pewnych okresach $30 \%$. Szacuje się, że w niewoli rosyjskiej zmarło łącznie około $14 \%$ jeńców ${ }^{61}$.

W oblężonych ambulatoriach chorych musiano umieszczać wprost na podłodze między łóżkami. Ci, którzy do nich trafiali, bynajmniej nie byli szczęściarzami. W niektórych obozach standardem było, że na łóżkach umieszczano po dwóch chorych. Nie było na nich ani poduszek, ani koców do nakrycia chorych. Zima syberyjska trwała nieraz 9-10 miesięcy, a minimalne temperatury czasami spadały do niemal $-50^{\circ} \mathrm{C}^{62}$. W większości ambulatoriów jedynym „lekarstwem”, które otrzymywali chorzy, był kipiatok, tj. gorąca woda (ros. кипяток). Ci, którzy nie zamarzli, umierali $z$ głodu lub $z$ powodu biegunki. Kiedy do takiego obozu, do tak sponiewieranych jeńców przybywały z pomoca materialną i z fachową opieką pielęgniarską Elsa i Ethel, ci, którzy tej chwili dożyli, zyskiwali szansę na ocalenie. Zdarzały się sytuacje, jak wspominała Elsa, że padali przed nimi na kolana i całując dłonie, płakali z radości ${ }^{63}$.

Działania inicjowane przez Elsę Brändström przyczyniły się z czasem do poprawy sytuacji egzystencjalnej jeńców niemieckich i austro-węgierskich w Rosji. To m.in. z jej inspiracji Szwedzki i Duński Czerwony Krzyż doprowadziły do zawarcia porozumienia pomiędzy Piotrogrodem a Berlinem i Wiedniem ws. dostarczania do obozów paczek (tzw. darów

60 E. Probst, Superfrauen 6-Medizin. Biografien berühmter Ärztinnen, Krankenschwestern, Hebammen und Stifterinnen [online], bmw 2013, [Dostęp: 26.01.2018]. Dostępny w World Wide Web: <https://goo.gl/Pbj9pb>.

61 Dla porównania śmiertelność wśród jeńców rosyjskich osadzonych w obozach niemieckich nieznacznie przekroczyła 5\%. Wszystkie przywołane dane podaje: G. Wurzer, Die Kriegsgefangenen der Mittelmächte in Russland im Ersten Weltkrieg [online]. Dissertation zur Erlangung des akademischen Grades Doktor der Philosophie in der Geschichtswissenschaftlichen Fakultät der Eberhard-Karls-Universität zu Tübingen. Hauptberichterstatter: prof. dr. Dietrich Beyrau, Tübingen 2000, s. 75 i n, [Dostęp: 26.01.2018]. Dostępny w World Wide Web: <https://goo.gl/BqfpPj>. Por. statystyki śmiertelności wśród jeńców rosyjskich w obozach niemieckich: A. Marcinkiewicz, Śmiertelność jeńców wojennych wlatach 1914-1918 na terenie Prus Zachodnich, „Koło Historii” 2016, nr 19, s. 115-125.

62 Szwedzki Czerwony Krzyż odnotował przypadek wydania przez władze obozowe zakazu palenia w piecach. Według komendanta jeńcy mogli się ogrzewać ciepłem własnych ciał (E. Brändström, op. cit., s. 26).

63 Ibidem, s. 41. 
miłości) pochodzacych od organizacji charytatywnych i rodzin jeńców. Dzięki zgodzie obu wojujących stron na tę formę pomocy osadzonym mogli oni otrzymywać żywność, koce, leki, pieniądze i tytoń. Poprzez Szwecję do Rosji dotarło około tysiąca wagonów $z$ „darami miłości”ø4.

Nie wszyscy jeńcy mimo poprawy sytuacji egzystencjalnej byli skłonni oczekiwać końca wojny w syberyjskich barakach obozowych. Najbardziej zdeterminowani podejmowali ryzyko ucieczki. Tym, którzy się na nią decydowali, potrzebne były dokumenty. Jeden $z$ takich punktów, gdzie przed przekroczeniem granicy szwedzkiej można się było zaopatrzyć w fałszywki, znajdował się w samej stolicy państwa rosyjskiego. Prowadzono go w ścisłym centrum miasta przy Newskim Prospekcie w kierowanej przez Antoninę Leśniewska polskiej aptece ${ }^{65}$. Była to postać nietuzinkowa. W 1900 r. jako pierwsza kobieta w państwie carów uzyskała stopień magistra farmacji. Rok później otworzyła pionierską w skali Europy żeńską aptekę w Petersburgu. $Z$ racji na lokalizację nazywano ja polska apteka, funkcjonowała ona bowiem w gmachu Polskiego Towarzystwa Dobroczynności przy kościele św. Katarzyny przy Newskim Prospekcie. W momencie wybuchu Wielkiej Wojny Antonina Leśniewska zaczęła aktywnie działać na rzecz polskich jeńców z armii państw centralnych, m.in. w Polskim Towarzystwie Pomocy Ofiarom Wojny.

W Szwecji funkcjonowała specjalna organizacja nastawiona na niesienie pomocy uciekinierom $z$ niewoli rosyjskiej. Wynajmowała ona i opłacała fińskich przewodników, którzy pomagali zbiegłym jeńcom w przekraczaniu granicy ${ }^{66}$. Jej działalność koordynował Sven Unander piastujący przed wojna funkcję niemieckiego konsula honorowego w nadgranicznym mieście Haparanda. Wieść o „fińskim korytarzu ucieczkowym" ${ }^{\prime 67}$ szybko dotarła do najdalej położonych obozów jenieckich.

Wydostanie się $z$ Syberii czy Turkiestanu nie było jednak łatwe. Stąd też odsetek tych, którzy się decydowali na ucieczkę $z$ niewoli, w sto-

\footnotetext{
${ }_{64}$ Taka była wg E. Brändström skala pomocy zorganizowanej przez Berlin i Wiedeń w latach 1915-1920 (zob. Munzinger Online. Internationales Biographisches Archiv Personen: Elsa Brändström-Ulich, [Dostęp: 26.01.2018]. Dostępny w World Wide Web: $<$ https://goo.gl/vjqntD>).

65 A. Miodowski, Jeńcy austro-wegierscy $w$ niewoli rosyjskiej $w$ okresie przedrewolucyjnym (sierpien 1914 - luty 1917), „Białostockie Teki Historyczne” 2016, t. 14, s. 123.

66 Ibidem.

67 Szerzej na ten temat pisze: I. Nowikowa, O pobiegach niemieckich $i$ awstrijskich wojennoplennych czeriez Finlandiju w gody pierwoj mirowoj wojny [w:] Sankt Pietierburg i strany Siewiernoj Jewropy, red. kollektiw awtorow, Sankt Pietierburg 2007, s. 168-182.
} 
sunku do ogólnej liczby jeńców przetrzymywanych za Uralem był niewielki ${ }^{68}$. Tym, którzy zmuszeni byli oczekiwać końca wojny w obozowych barakach, należało nadal pomagać. Elsa Brändström i inne siostry Czerwonego Krzyża kontynuowały więc swoją misję w latach 1917-1920.

\section{Wnioski końcowe}

Po wybuchu rewolucji lutowej chaos w Rosji jeszcze się pogłębił. Wbrew oczekiwaniom czerwonokrzyskich sióstr demokratyzacja nie przyniosła zmiany polityki państwa wobec jeńców. Ich sytuacja pogorszyła się jeszcze bardziej po przejęciu władzy przez bolszewików. Nawet pokój brzeski z marca 1918 r. - mimo zapoczatkowania repatriacji - nie zakończył gehenny jeńców. Badacze oceniaja, że czerwonokrzyskie siostry $z$ Elsą Brändström na czele i współpracujące $z$ nimi wolontariuszki, takie jak Antonina Leśniewska, swoim zaangażowaniem w niesienie pomocy jeńcom w latach 1914-1920 ocaliły życie co najmniej 100 tys. z nich ${ }^{69}$. Szwedzki Czerwony Krzyż skierował do Rosji blisko 80 wolontariuszek i wolontariuszy. Obok nich aktywne były też czerwonokrzyskie siostry z Niemiec, Austro-Węgier, Danii, Stanów Zjednoczonych, Kanady oraz Polki $z$ diaspory w Rosji. Ich poczynania nie tylko przyczyniały się do ratowania zdrowia i życia jeńców, lecz także poprzez codzienne egzekwowanie u władz obozowych przestrzegania zapisów IV Konwencji Haskiej przywracały im ludzką godność. W wojenno-rewolucyjnych realiach rosyjskich było to niezwykle istotne.

Elementem opieki pielęgniarskiej w latach Wielkiej Wojny stała się też świadczona przez siostry czerwonokrzyskie podstawowa pomoc psychologiczna. Choć niosły ja tylko w postaci zwykłej rozmowy (wysłuchania), to była ona dla chorych i rannych jeńców czasami równie ważna, jak ta stricte medyczna (ratująca zdrowie i życie). W tym sensie każda $z$ czerwonokrzyskich sióstr przyczyniła się nie tylko do dalszego

\footnotetext{
68 Według danych urzędowych miesięcznie uciekało z Syberii Zachodniej do 400 jeńców. Na przykład w okresie pomiędzy 24 listopada a 28 grudnia 1916 r. na ten krok zdecydowało się 388 jeńców -310 austro-węgierskich i 78 niemieckich (A. Miodowski, op. cit., s. 118). Czy do ucieczek dochodziło też po 7 listopada 1917 r.? (zob. Idem, Sytuacja jeńców wojennych $z$ armii państw centralnych $w$ niewoli rosyjskiej po przewrocie bolszewickim (listopad 1917 - marzec 1918) [w:] Wielka Wojna poza linia frontu, red. D. Grinberg, J. Snopko, G. Zackiewicz, Białystok 2013, s. 363-372).

${ }^{69}$ J. Čerkasskij, Angely Pervoj mirovoj, „Russkaja Germanija” 2017, No. 10, [Dostęp: 26.01.2018]. Dostępny w World Wide Web: <https://goo.gl/wWmPfU>.
} 
rozwoju (ubogacenia) wiedzy pielęgniarskiej, lecz także do absorbowania jej osiagnięć przez medycynę zaplecza pola walki.

Postęp w dziedzinie opieki pielęgniarskiej nie był oczywiście tak spektakularny, jak np. dokonania Marii Curie-Skłodowskiej w dziedzinie medycyny wojskowej, na której grunt przeniosła najnowsze osiagnięcia naukowo-techniczne, m.in. konstruując i jako pierwsza stosując na froncie zachodnim urzadzenia rentgenowskie do identyfikacji złamań i lokalizowania odłamków szrapneli u rannych żołnierzy ${ }^{70}$. Tym niemniej powrót do zdrowia nawet najlepiej zdiagnozowanego przez radiologa i zoperowanego przez lekarza rannego żołnierza (zwłaszcza jeńca) nie byłby możliwy bez zapewnienia mu fachowej opieki pielęgniarskiej, elementarnej pomocy psychologicznej i zwyczajnej ludzkiej troski. To wszystko w realiach wojennych mogły zaoferować potrzebujacym przede wszystkim czerwonokrzyskie siostry. Dzięki nim w okresie Wielkiej Wojny rozwój wiedzy medycznej (medycyny zaplecza pola walki) mógł się dokonać w sposób komplementarny $z$ postępem wiedzy pielęgniarskiej.

\section{Bibliografia}

\section{Źródła}

Als Österreichische Rotkreuzschwester in Russland. Tagebuch von Gräfin Anna Revertera, „Süddeutsche Monatshefte” 1923, September, s. 252281.

Bericht der Dänischen Roten-Kreuz-Delegation zum Besuch der deutschen Kriegsgefangenenlager in Russland, der deutschen Schwester, Oberin Gräfin Alexandrine Üxküll-Gyllenband und des Dänischen Obersten G. C. Muus [w:] Völkerrechtswidrige Behandlung der deutschen Kriegsgefangenen in Russland, Berlin : Preussisches Kriegsministerium, 1918, Band 2, Anlage 413.

\footnotetext{
${ }^{70} \mathrm{Na}$ prośbę francuskiego Ministerstwa Wojny Maria Curie-Skłodowska włączyła się w wyszkolenie zespołów asystentów-radiologów. W większości były to kobiety. Na bazie własnych wykładów zredagowała książkę Radiologia i wojna (zob. M. Curie, La radiologie et la guerre [online], Paris 1921, [Dostęp: 28.11.2017]. Dostępny w World Wide Web: $<$ http://bit.ly/2hZydzd>). Szerzej o wojennym zaangażowaniu noblistki pisze: W. Śladkowski, Dla Polski i Francji. Maria Curie-Skłodowska w latach I wojny światowej, „Annales Universitatis Mariae Curie-Skłodowska, Sectio F, Historia” 2011, Vol. 66, z. 1, s. 67-77.
} 
Brändström Elsa, Unter Kriegsgegangenen in Rusland und Sibirien (19141920), Berlin 1922, s. 8 [online], [Dostęp: 16.01.2018]. Dostępny w World Wide Web: <https://goo.gl/kC4gsh>.

Curie Marie, La radiologie et la guerre, Paris 1921, [online], [Dostęp: 28.11.2017]. Dostępny w World Wide Web: <http://bit.ly/2hZydzd>.

Der Weltkampf um Ehre und Recht : die Erforschung des Krieges in seiner wahren Begebenheit, auf amtlichen Urkunden und Akten beruhend, red. Max Schwarte, Berlin : Verlag von Johann Ambrosius Barth in Leipzig und Walter de Gruyter in Berlin, 1919, s. 182 [online], [Dostęp: 16.01.2018]. Dostępny w World Wide Web: <https://goo.gl/ZBbK2X>. Dyboski Roman, Siedem lat $w$ Rosji i na Syberji (1915-1921). Przygody i wrażenia, Warszawa : Gebethner i Wolff, 1922.

Gagern Elisabeth von, Nür Frauen. Die Ordensidee Maria Wards, München : Filser, 1949.

Hadeln Charlotte von, Deutsche Frauen, Deutsche Treue 1914-1933. Ein Ehrenbuch der deutschen Frau, Berlin : Traditions Verlag Kolk \& Co, 1935. Juszczak Kazimierz Wawrzyniec, Szlakiem jeńców z Turkiestanu do niepodległej Polski, Poznań : Dom Rzemieślniczy, 1928.

Kessler Harry, Tagebücher 1918-1937. Gesamtausgabe (Kapitel 9. Inschrift: Berlin. 22 Februar 1926. Montag), [online], [Dostęp: 26.01.2018]. Dostępny w World Wide Web: <https://goo.gl/j17J3m>.

Kinsky Nora, Russisches Tagebuch 1916-1918, Stuttgart : Busse Seewald, 1976, ISBN 3512004075.

Mihalotzy Käthe von, Eine Reise durch Kriegsgefangenenlager in Russland und Turkestan [w:] Feindeshand: die Gefangenschaft im Weltkriege in Einzeldarstellungen, ed. Hans Weiland, Leopold Kern, Wien : Bundesvereinigung der ehemaligen österreichischen Kriegsgefangenen, 1931, Band 2, s. 251-255.

Munzinger Online. Internationales Biographisches Archiv - Personen: Elsa Brändström-Ulich, [Dostęp: 26.01.2018]. Dostępny w World Wide Web: $<$ https://goo.gl/vjqntD>.

Polacy $w$ Turkiestanie $w$ okresie wojny światowej, red. Stanisław Żelazowski [et al.], Warszawa : Grono byłych Turkiestańczyków-Polaków, 1931.

Revertera Anna, Als Rotkreuzschwester in Russland und Sibirien [w:] Feindeshand: die Gefangenschaft im Weltkriege in Einzeldarstellungen, ed. Hans 
Weiland, Leopold Kern, Wien : Bundesvereinigung der ehemaligen österreichischen Kriegsgefangenen, 1931, Band 2, s. 245-251.

Üxküll-Gyllenband Alexandrine Gräfin von, Aus einem Schwesternleben, Stuttgart : Kohlhammer-Verlag, 1956.

Walsleben (Steinaecker) Magdalene von, Die deutsche Schwester in Sibirien: Aufzeichnungen von einer Reise durch die sibirischen Gefangenenlager vom Ural bis Wladiwostok, Berlin : Furche-Verlag, 1919, [online], [Dostęp: 26.01.2018]. Dostępny w World Wide Web: <https://goo.gl/ AGj3vZ>.

Wenzel Anne-Marie, Deutsche Kraft in Fesseln. Fünf Jahre deutscher Schwesterndienst in Sibirien (1916-1927), Potsdam : Ernte-Verlag, 1931.

„Wiestnik Omskogo Gorodskogo Obszczestwiennogo Uprawlenija” 1915, No. $6 / 7$.

Zemła Józef, W obozach jeńców wojennych na Syberji, Warszawa : Gebethner i Wolff, 1934.

\section{Opracowania}

Bączyk Jarosław, Armie za drutami. Jeńcy wojenni na terenie prowincji poznańskiej (1914-1918), Poznań : Wielkopolskie Muzeum Niepodległości, 2015, ISBN 978-83-935127-5-1.

Čajka Juliâ, Daša Sevastopol'skaâ - geroinâ Krymskoj vojny, [Dostęp: 16.01.2018]. Dostępny w World Wide Web: <https://goo.gl/93JYiL>.

Čerkasskij Jakov, Angely Pervoj mirovoj, „Russkaja Germanija” 2017, No. 10, [Dostęp: 26.01.2018]. Dostępny w World Wide Web: <https://goo.gl/ wWmPfU>.

The Crimean Journals of the Sisters of Mercy 1854-56, edited by Maria Luddy, Dublin : Four Courts Press, 2004, [online], [Dostęp: 16.01.2018]. Dostępny w World Wide Web: <https://goo.gl/VZKLWd>.

Drozdowska Agnieszka, Kobiety a działalność Czerwonego Krzyża na ziemiach polskich zaboru rosyjskiego w latach 1914-1916 na podstawie wspomnień lekarza Czerwonego Krzyża oraz Laury de Turczynowicz, "Czasopismo Naukowe Instytutu Studiów Kobiecych” 2017, nr 1 (2), s. 73-91, DOI 10.15290/cnisk.2017.01.02.04. 
Drozdowska Agnieszka, Kobiety z ziem Królestwa Polskiego i Obwodu Białostockiego podczas pierwszej wojny światowej, praca mag., Uniwersytet w Białymstoku, Białystok : Uniw. Dysert, 2017.

Ėtničeskij atlas Uzbekistana, red. Alisher Ilkhamov [online], [Dostęp: 26.01.2018]. Dostępny w World Wide Web: <https://goo.gl/toaCKY>.

Gantert Timo, Deutsche und österreichische Kriegsgefangene des Ersten Weltkriegs in russisch-sowjetischem Gewahrsam. Dissertation Institut für Geschichte der Medizin der Ruprecht-Karls-Universität Heidelberg. Hauptberichterstatter: prof. dr Wolfgang U. Eckart, 2008, Heidelberg : Univ. Diss., 2009, [online], [Dostęp: 26.01.2018]. Dostępny w World Wide Web: <https://goo.gl/8RKRhm>.

Grey Elizabeth, Friend Within the Gates. The Story of Nurse Edith Cavell, Boston : Houghton Mifflin Co, 1961. ISBN 0-395-06786-3, [online], [Dostęp: 17.01.2018]. Dostępny w World Wide Web: <https://goo.gl/ck5YR4>.

Hämmerle Christa, Heimat/Front. Geschlechtergeschichte/n des Ersten Weltkriegs in Österreich-Ungarn, Wien : Böhlau Verlag, 2014, s. 279, ISBN 978-3205794714.

Hardy Anne, Actions not Words. Thorvald Madsen, Denmark, and International Health 1902-1939, DOI: http://dx.doi.org/10.3726/978-3-65305156-8 [w:] Of Medicine and Men. Biographies and Ideas in European Social Medicine between the World Wars, ed. Iris Borowy, Anne Hardy, Frankfurt a. M. : Peter Lang Verlag der Wissenschaften, 2008, s. 127144, [online], [Dostęp: 26.01.2018]. Dostępny w World Wide Web: <https://goo.gl/WNxGaE>, ISBN 978-3-631-58044-8.

Internacionalisty, red. kollektiw awtorow, Moskva 1971.

Internacionalisty. Trudâŝčijsâ zarubiežnych stran - učastniki borby za wlast Sowietow, red. Aleksandr Manusevič, Moskva 1967.

Internacionalisty. Učastie trudâsčihsâ stran central'noj ijûgovostočnoj Evropy $v$ bor' be za vlast' Sovetov $v$ Rossii 1917-1920 gg., red. Aleksandr Manusevič, Moskva : Izdatel'stvo Nauka, 1987, [online], [Dostęp: 16.01.2018]. Dostępny w World Wide Web: <https://goo.gl/Tcehbk>.

Juhl Eduard, Klante Margarete, Epstein Herta, Brändström. Weg und Werk einer grossen Frau in Schweden, Sibirien, Deutschland, Amerika, Stuttgart : Evang. Buchgem., 1962.

Karpus Zbigniew, Jeńcy rosyjscy i bolszewiccy $w$ Tucholi (1914-1922) [w:] Tuchola: obóz jeńców i internowanych 1914-1923, t. 1, cz. 3: Warunki 
życia jeńców i internowanych, red. Zbigniew Karpus, Waldemar Rezmer, Seria: Obozy jeńców i internowanych na ziemiach polskich 1914-1924, Torun : Wydawnictwo Naukowe Uniwersytetu Mikołaja Kopernika, 2007, s. 43-48, ISBN 978-83-231-2070-4.

Karpus Zbigniew, Obozy jeńców wojennych $z$ państw Ententy na ziemiach polskich pod panowaniem pruskim (1914-1918) [w:] Spoleczeństwo polskie na ziemiach pod panowaniem pruskim w okresie I wojny światowej, red. Mieczysław Wojciechowski, Torun : Uniwersytet Mikołaja Kopernika, 1996, s. 149-162.

Krestovozdviženskaâ obŝina siester miloserdiâ [w:] Ėnciklopediâ blagotvoritel'nosti. Sankt-Peterburg [Dostęp: 16.01.2018]. Dostępny w World Wide Web: <https://goo.gl/3Ssrt1>.

Marcinkiewicz Alicja, Śmiertelność jeńców wojennych w latach 1914-1918 na terenie Prus Zachodnich, „Koło Historii” 2016, nr 19, s. 115-125.

Meehan Therese C., Irish Nurses at the Crimean War [Dostęp: 16.01.2018]. Dostępny w World Wide Web: <https://goo.gl/Z1uZCF>.

Miodowski Adam, Jeńcy austro-wegierscy $w$ niewoli rosyjskiej $w$ okresie przedrewolucyjnym (sierpień 1914- luty 1917), „Białostockie Teki Historyczne" 2016, t. 14, s. 111-130.

Miodowski Adam, Sytuacja jeńców wojennych z armii państw centralnych $w$ niewoli rosyjskiej po przewrocie bolszewickim (listopad 1917 - marzec 1918) [w:] Wielka Wojna poza linia frontu, red. nauk. Daniel Grinberg, Jan Snopko, Grzegorz Zackiewicz, Białystok : Instytut Historii i Nauk Politycznych Uniwersytetu w Białymstoku, 2013, s. 363-372.

Moritz Verena, Leidinger Hannes, Gefangenschaft, Revolution, Heimkehr. Die Bedeutung der Kriegsgefangenenproblematik für die Geschichte des Kommunismus in Mittel- und Osteuropa 1917-1920, Wien : Böhlau, 2003, ISBN 9783205770688, [online], [Dostęp: 26.01.2018]. Dostępny w World Wide Web: <https://goo.gl/HQN5su>.

Nachtigal Reinhard, Die dänisch-österreichisch-ungarischen Rotkreuzdelegierten in Russland 1915-1918. Die Visitationen der Kriegsgefangenen der Mittelmächte durch Fürsorgeschwestern des österreichischen und ungarischen Roten Kreuzes, „Zeitgeschichte” 1998, No. 25, s. 366-374, ISSN 0256-5250. 
Nachtigal Reinhard, Kriegsgefangene der Habsburgermonarchie in Russland, „Österreich in Geschichte und Literatur mit Geographie” 1996, Vol. 40, s. 248-262, ISSN 1013-9966.

Nachtigal Reinhard, Zur Anzahl der Kriegsgefangenen im Ersten Weltkrieg, „Militargeschichtliche Zeitschrift” 2008, No. 2, s. 345-384, DOI: https:// doi.org/10.1524/mgzs.2008.67.2.345.

Nowikowa Irina, O pobiegach niemieckich $i$ awstrijskich wojennoplennych czeriez Finlandiju $w$ gody pierwoj mirowoj wojny [w:] Sankt Pietierburg $i$ strany Siewiernoj Jewropy, red. kollektiw awtorow, Sankt Pietierburg 2007, s. 168-182.

Ölçen Mehmet Arif, Vetluga memoire. A Turkish prisoner of war in Russia 1916-1918, transl. Gary Leiser, Gainesville : University Press of Florida, 1995, ISBN 9780585178165, [online], [Dostęp: 26.01.2018]. Dostępny w World Wide Web: <https://goo.gl/mF8SpB>.

Probst Ernst, Superfrauen 6 - Medizin. Biografien berühmter Ärztinnen, Krankenschwestern, Hebammen und Stifterinnen, bmw : GRIN Verlag, 2013, e-ISBN 9783640395026, [online], [Dostęp: 26.01.2018]. Dostępny w World Wide Web: <https://goo.gl/Pbj9pb>.

Rachamimov Alon, Alltagssorgen und politische Erwartungen. Eine Analyse von Kriegsgefangenenkorrespondenzen in den Beständen des Österreichischen Staatsarchivs, „Zeitgeschichte” 1998, No. 25, s. 350-351, ISSN 0256-5250.

Rachamimov Alon, POWs and the Great War. Captivity on the Eastern Front, Oxford : Berg Publishers, 2002.

Sibirskaja sovietskaja encyklopiedija, t. 1, red. Mark Azadovskij i dr., Moskva : Sibirskoe kraevoe izdatel'stvo, 1929.

Snopko Jan, $Z$ problemów opieki nad polskimi jeńcami $w$ obozach państw centralnych w latach pierwszej wojny światowej (1914-1918) [w:] Z dziejów Rosji i Polski w XX wieku. Ksiega dedykowana prof. Richardowi Pipesowi, red. Henryk Kocój, Radosław Małek, Marek Szczerbiński, Gorzów Wielkopolski : Sonar, 2006, s. 193-203, ISBN 83-88784-33-1.

Śladkowski Wiesław, Dla Polski i Francji. Maria Curie-Skłodowska w latach I wojny światowej, „Annales Universitatis Mariae Curie-Skłodowska, Sectio F, Historia" 2011, Vol. 66, z. 1, s. 67-77.

Wurzer Georg, Die Kriegsgefangenen der Mittelmächte in Russland im Ersten Weltkrieg. Dissertation zur Erlangung des akademischen Grades Dok- 
tor der Philosophie in der Geschichtswissenschaftlichen Fakultät der Eberhard-Karls-Universität zu Tübingen. Hauptberichterstatter: prof. dr. Dietrich Beyrau, Tübingen : Univ. Diss., 2000, [online], [Dostęp: 26.01.2018]. Dostępny w World Wide Web: <https://goo.gl/BqfpPj>.

Yanikdag Yucel, Ottoman Prisoners of War in Russia 1914-22, „Journal of Contemporary History” 1999, Vol. 34, No. 1, p. 69-85, [online], [Dostęp: 26.01.2018]. Dostępny w World Wide Web: <https://goo.gl/vZmHWv>. 